\title{
COST-EFFECTIVE MITIGATION STRATEGIES FOR RESIDENTIAL BUILDINGS IN AUSTRALIAN FLOOD PLAINS
}

\author{
T. MAQSOOD, M. WEHNER, K. DALE \& M. EDWARDS \\ Geoscience Australia and Bushfire \& Natural Hazards Cooperative Research Centre, Australia.
}

\begin{abstract}
In recent years, floods have impacted many Australian communities. The floods have resulted in significant logistics for emergency management and considerable costs to all levels of government and property owners to undertake damage repair and enable community recovery.

These impacts are fundamentally the result of inappropriate development on floodplains and a legacy of high risk building stock in flood-prone areas. The Australian Bushfire and Natural Hazards Collaborative Research Centre project entitled "Cost-effective mitigation strategy development for flood-prone buildings" aims to address this issue and is targeted at assessing mitigation strategies to reduce the vulnerability of existing residential building stock in Australian floodplain area.

This paper presents the outcomes of this ongoing project. Key tasks of the project include: (1) a classification of residential building stock, (2) a review of flood mitigation strategies, (3) vulnerability assessment of typical building types with and without mitigation, and (4) benefit cost analyses of all retrofit options for a range of severity/likelihood of flood hazard covering a selection of catchment types. The work will provide information on the optimal retrofit strategies in the context of Australian construction costs and catchment characteristics.

The research will also entail experimental testing of preferred materials to ascertain their resilience to flood water exposure. The outcome of this research will be an evidence base to inform decisions about mitigating the risk posed by buildings on floodplains. The information will be targeted to all levels of government, insurance industry and private property owners.

Keywords: Australia, cost-effectiveness, mitigation, vulnerability.
\end{abstract}

\section{INTRODUCTION}

Globally, floods cause tremendous damage with loss of life and property. An analysis of global statistics conducted by Jonkman [1] showed that floods (including coastal flooding) caused 175,000 fatalities and affected more than 2.2 billion people between 1975 and 2002.

In Australia, floods cause more damage on an average annual cost basis than any other natural hazard [2]. The fundamental causes of this level of damage and the key factor contributing to flood risk, in general, is the presence of vulnerable buildings constructed within floodplain areas due to ineffective land-use planning. Recent events in Australia (2011, 2013 and 2015) have highlighted the vulnerability of housing to flooding (see Fig. 1).

While there is now a construction standard published by the Australian Building Code Board [3] for new construction in some types of flood-prone areas, there is a large proportion of the existing building stock that has been built in flood-prone areas across Australia [2].

The Bushfire and Natural Hazards Collaborative Research Centre (BNHCRC) project entitled "Cost-effective mitigation strategy development for flood-prone buildings" is examining 

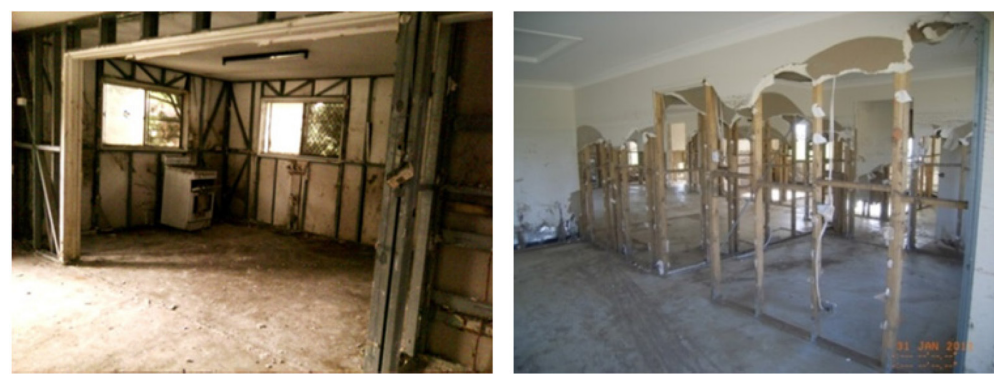

Figure 1: Examples of building damage after 2011 Queensland flooding.

the opportunities for reducing the vulnerability of Australian residential buildings to flood [4]. It addresses the need for an evidence base to inform decision making on the mitigation of the flood risk posed by the most vulnerable Australian building types. This project investigates methods for the upgrading of existing residential building stock in floodplains to increase their resilience in future flood events.

\section{PROJECT ACTIVITIES}

Information on the vulnerability of buildings and factors affecting vulnerability is fundamental to evaluating mitigation strategies to reduce future losses. Therefore, this BNHCRC project is systematically developing information about residential building types in Australia, their vulnerability and possible mitigation measures to reduce their vulnerability.

To date, a building classification schema has been developed to categorise Australian residential buildings into a finite set of typical building types [5]. A literature review of flood mitigation strategies applied internationally has also been conducted. Each mitigation strategy is being evaluated and will be costed through the engagement of professional quantity surveyors. Cost benefit analyses will be conducted to determine optimum retrofit strategies for selected building types applicable to a range of catchment behaviours.

\subsection{Development of building schema}

This research requires the context of a building vulnerability classification, or schema. The classes identified within the schema have to represent the variety of housing within the nation's residential building stock and, more specifically, the variation in vulnerability across the nation's building stock. Furthermore, the schema must identify specific classes for which the project will develop mitigation strategies.

In this research a literature review has been conducted which reviewed building schemas developed nationally and internationally for a range of uses within different projects. The reviewed schemas are from the USA [6], Germany [7], Philippines [8], New Zealand [9], Australia [10] and UNISDR Global Assessment Report [11].

After the literature review, a new schema was proposed that represents a fundamental shift from describing the complete building as an entity to one that focuses on sub-components. The schema divides each building into its major components (i.e. foundation, ground floor, upper floors (if any) and roof) enabling the vulnerability of each of these components to be assessed separately (Fig. 2). Each storey type is then classified using the following six attributes. 


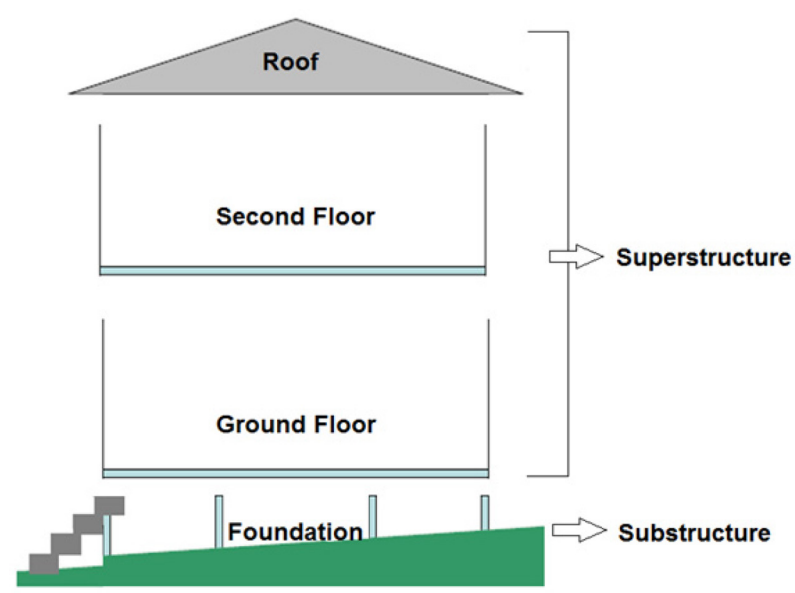

Figure 2: Building structure divided into main components.

- Construction period (pre-1960 or post-1960)

- Fit-out quality (standard or low)

- Storey height (3.0 m or $2.7 \mathrm{~m}$ or $2.4 \mathrm{~m})$

- Bottom floor system (slab-on-grade or raised timber or raised chipboard)

- Internal wall material (masonry or plasterboard or timber)

- External wall material (brick veneer or weatherboard or masonry)

With the exclusion of combinations that are invalid in an Australian context, the schema defines 60 discrete vulnerability classes based on the above- mentioned attributes. Furthermore, the schema proposed six roof types based on material and pitch of the roof.

This new approach facilitates the development of vulnerability models for taller buildings, buildings with basements, buildings with mixed usages and those with different construction materials used at different floor levels.

\subsection{Literature review of mitigation strategies}

A literature review has been conducted to identify mitigation strategies used in several countries and for various severities of flooding. The review has considered literature available through peer-reviewed journals, international conferences, research reports and guideline documents.

Bouwer et al. [12] classified the different types of retrofit or mitigation measures into nine basic categories in which a distinction was made between mitigation measures that focus on hazard reduction and those that focus on vulnerability reduction. The use of insurance to recover from a disaster and to provide incentives for mitigation works was studied by Kunreuther [13] and Crichton [14]. The use of spatial zoning and land-use changes was presented by Burby et al. [15] and Poussin et al. [16]. Another widely used broader classification of mitigation measures is based on whether the strategies utilise engineering and administrative methods to reduce flood risk or modify the flood characteristics and human occupancy of the floodplain. These are broadly divided into structural and non-structural approaches [17] or hard and soft measures [18]. Both approaches have their own benefits and limitations. 
A summary of mitigation strategies that have been applied in Australia and internationally to minimise vulnerability and future losses of residential buildings is given below.

\subsubsection{Elevation}

Elevation of a structure is one of the most common mitigation strategies which aims to raise the lowest floor of a building above the expected level of flooding (Fig. 3). This can be achieved, for example, by extending the walls of an existing structure and raising the floor level; by constructing a new floor above the existing one; or through raising the whole structure on new foundations.

The technical considerations that need to be taken into account in raising buildings are structure type, construction material, foundation type, building size, flood characteristics and other hazards [19].

Generally, the least expensive and easiest building to elevate is a low-set single storey timber frame structure [20]. The procedure becomes complicated and expensive when other factors are included such as a slab-on-grade construction, walls of masonry or concrete or a multi-storey building [21]. Currently elevation of a structure is one of the strategies which result in incentives from the insurance industry in the form of reductions in annual premiums for flood insurance [22]. An analysis conducted by FEMA [23] showed that house owners can break even on their investment in adopting this mitigation strategy in little over 5 years due to reductions in their flood insurance premiums.

\subsubsection{Relocation}

Relocation of a building is the most dependable technique in mitigation of flood risk. However, it is generally the most expensive as well [21]. Relocation involves moving a structure to a location that is less prone to flooding and normally involves placing the structure on a wheeled vehicle and then transporting it to a new location and setting it on a new foundation [19]. The bulk of relocation cost includes cost of new land, transportation and reconnection of services. This strategy is much easier and cost effective for low-set timber frame structures. The relocation of slab-on-grade structures is more complicated and expensive. In this case, there are two approaches to relocating, that is, detaching the structure from the slab or moving the structure with the slab attached [24].

Relocation is most appropriate in areas where flood conditions are severe such as a high likelihood of deep flooding, or where there is high flow velocity with short warning time and a significant quantity of debris.

The technical considerations for relocation include structure type, its size and condition. Light weight timber structures are easy to transport compared to heavy masonry and concrete

(A) House before elevation

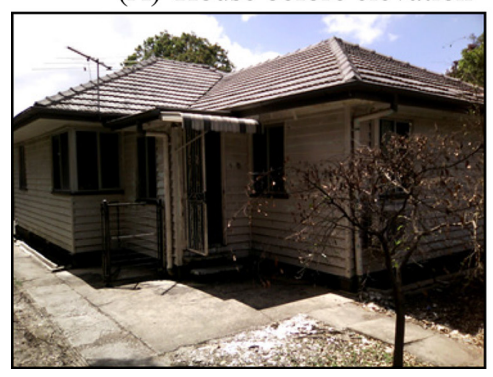

(B) House after elevation

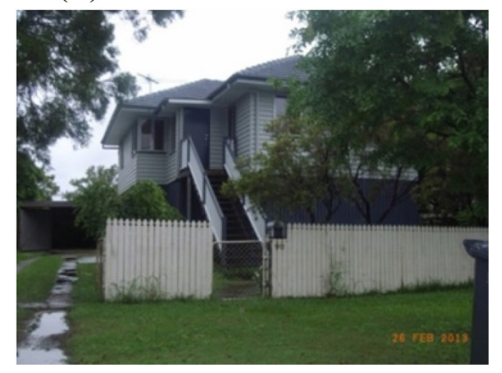

Figure 3: Example of elevating floor levels. 
buildings. Similarly, relocation of single storey compact size structures is far easier than for large multi-storey structures. Further, the structure should be in good condition and able to withstand the stresses imposed when the structure is lifted and relocated [25].

\subsubsection{Dry floodproofing}

In dry floodproofing, the portion of a structure that is below the expected flood level is sealed to make it substantially impermeable to floodwaters. Such an outcome is achieved by using sealants which include wall coatings, waterproofing compounds, impervious sheeting over doors and windows and a supplementary leaf of masonry [19]. The expected duration of flooding is critical when deciding which sealant systems to use because seepage can increase with time making flood proofing ineffective [21]. Preventing sewer backflow by using backwater valves is also important in making dry floodproofing effective $[25,26]$. Sump pumps are also required to drain out the water which may leak through small openings or exterior walls [27].

The flood characteristics which can affect the success of dry floodproofing are flood depths, flow velocity, flood duration, flood borne debris and length of warning time [25].

Dry floodproofing is generally not recommended in flood depths exceeding one metre based on tests carried out by the US Army Corps of Engineers as the stability of the building becomes an issue over this threshold depth [26, 28]. Dry floodproofing may also be inappropriate for light timber frame structures and structures which are not in good condition and may not be able to withstand the forces exerted by the floodwater [19].

\subsubsection{Wet floodproofing}

In this measure, the building is modified and floodwater is allowed to enter into the building to equalise the hydrostatic pressure on the interior and exterior of the building and thus reduces the chance of building failure [21, 25]. With this technique, as all the building components below the flood level are wetted, all construction material and fit-outs should be water-resistant and/or can be easily cleaned following a flood extent [29, 30]. Wet floodproofing involves raising utilities including heating, ventilation, air conditioning and electrical systems. It also include raising important contents above the expected flood level, installing flood openings to equalise the hydrostatic pressure exerted by floodwaters and installing pumps to remove floodwater if the building has a basement [31].

Wet floodproofing may not be suitable in floods with duration of more than a day as longer exposure to flood water leads to damage to structural components of the building and also results in the growth of algae and mould [25]. In a study conducted by Kreibich et al. [26], wet floodproofing through adapted use (changing ground floor usage), adapted interior finishes (use of flood resistant materials) and installing utilities at higher levels has resulted in reductions of building mean damage by $46 \%, 53 \%$ and $36 \%$, respectively, in Germany during the 2002 floods.

\subsubsection{Flood barrier}

Flood barriers considered in this research are those built around a single building and are normally placed some distance away from it to avoid any structural modifications to the building. There are two kinds of barriers: permanent and temporary. An example of a permanent barrier is a floodwall which is quite effective because it requires little maintenance and can be easily constructed and inspected. There are also several types of temporary flood barriers available in the market which can be moved, stored and reused. There are a number of considerations with regard to the use of these barriers such as the need for prior 
warning and enough time to be set up to be effective [32]. They also require periodic inspection and maintenance to address any repairs required. Further, access to the building could be difficult [25].

A number of vendors make temporary flood barriers that can be assembled relatively easily, moved into place and anchored. Example flood barriers include sand bags, PVC tubes, box wall, flexible barriers, box barrier and metal fence [33]. In a study in Germany, the mean damage ratio was reduced by $29 \%$ for the cases where water barriers were available during the 2002 floods [26].

\subsection{Development of Australian specific retrofit options and costing}

A limited number of typical residential storey types have been selected for the balance of the research which are based on the schema proposed earlier in this paper. Fig. 4 presents the six floor types for which retrofit strategies will be investigated. Key characteristics of these floor

(A) Type 1

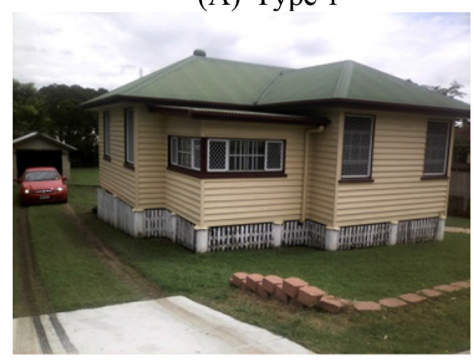

(C) Type 3

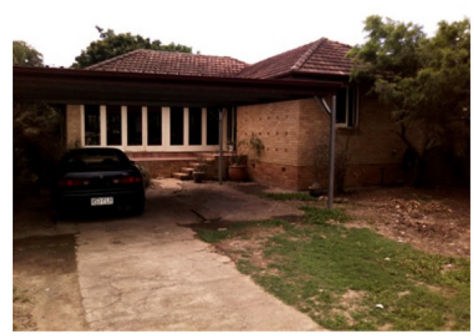

(E) Type 5

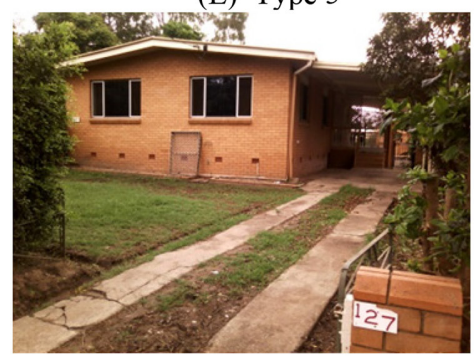

(B) Type 2

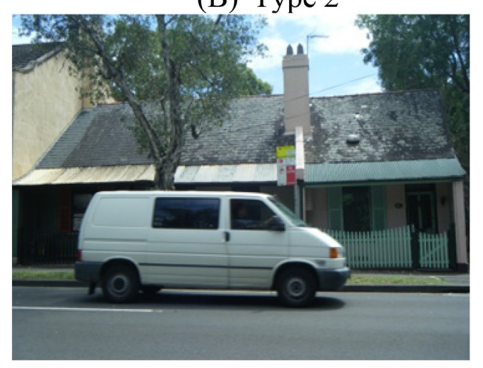

(D) Type 4

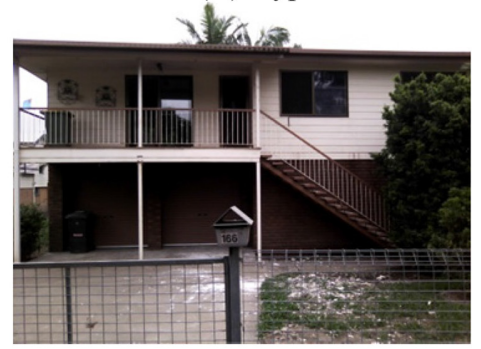

(F) Type 6

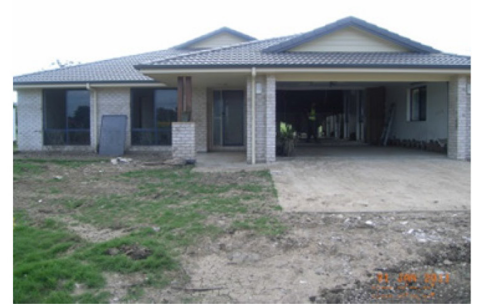

Figure 4: Selected typical residential floor types. 
Table 1: Characteristics of selected storey types.

\begin{tabular}{lllllll}
\hline Type & $\begin{array}{l}\text { Const. } \\
\text { period }\end{array}$ & $\begin{array}{l}\text { Fit-out } \\
\text { quality }\end{array}$ & $\begin{array}{l}\text { Storey } \\
\text { height }\end{array}$ & Floor type & $\begin{array}{l}\text { Internal wall } \\
\text { material }\end{array}$ & $\begin{array}{l}\text { External wall } \\
\text { material }\end{array}$ \\
\hline 1 & Pre-1960 & Standard & $3.0 \mathrm{~m}$ & Raised Timber & Timber & Weatherboard \\
2 & Pre-1960 & Standard & $2.7 \mathrm{~m}$ & Slab-on-grade & Masonry & Solid masonry \\
3 & Pre-1960 & Low & $2.7 \mathrm{~m}$ & Raised Timber & Timber & Cavity masonry \\
4 & Post-1960 & Standard & $2.4 \mathrm{~m}$ & Raised Timber & Plasterboard & Weatherboard \\
5 & Post-1960 & Low & $2.4 \mathrm{~m}$ & Raised Timber & Plasterboard & Brick veneer \\
6 & Post-1960 & Standard & $2.7 \mathrm{~m}$ & Slab-on-grade & Plasterboard & Brick veneer \\
\hline
\end{tabular}

Table 2: Floodproofing matrix for selected Australian floor types.

\begin{tabular}{|c|c|c|c|c|c|}
\hline \multirow[t]{2}{*}{ Type } & \multicolumn{5}{|c|}{ Flood mitigation strategies } \\
\hline & Elevation & Relocation & Dry floodproofing & Wet floodproofing & Flood barriers \\
\hline 1 & & & N/A & & \\
\hline 2 & N/A & N/A & & & \\
\hline 3 & & N/A & N/A & & \\
\hline 4 & & N/A & N/A & & \\
\hline 5 & & N/A & N/A & & \\
\hline 6 & N/A & N/A & & & \\
\hline
\end{tabular}

types are presented in Table 1. Further, based on the characteristics of the selected storey types a floodproofing matrix has been developed which excludes the mitigation options mentioned in Section 2.2 that are invalid in the Australian context (see Table 2). Costing modules are being developed for quantity surveying specialists to estimate the mitigation cost of all appropriate strategies for these six floor types.

\section{FUTURE ACTIVITIES}

A brief overview of the future activities of the project is given below.

\subsection{Experimental testing of selected building materials}

In this project, the strength implications of immersion of key structural elements will be examined to ascertain where deterioration due to wetting and subsequent drying needs to be addressed as part of repair strategies. An analysis will be conducted to identify research gaps in building material susceptibility to flood water in Australia. This research will also entail experimental testing of preferred material types to ascertain their resilience to flood water exposure.

3.2 Vulnerability assessment for current and retrofitted building types

The vulnerability of selected floor types to a wide range of inundation depths will be assessed. It will also be supplemented by both a significant body of flood vulnerability research by Geoscience Australia and a body of damage survey activity in Australia. 


\subsection{Benefit versus cost analysis}

Retrofit options entail an investment that will realise a benefit over future years through reduced average annualised loss. Decisions to invest in reducing building vulnerability, either through asset owner initiatives or incentives provided by government or the insurance industry, will depend upon the benefit versus cost of the retrofit. In this research, all retrofit options will be assessed through a consideration of a range of severity and likelihood of flood hazard covering a selection of catchment types.

\subsection{Outcomes}

The result will be an evidence base to inform decision making by government and property owners on mitigation of flood risk by providing information on the cost-effectiveness of different mitigation strategies and optimal solutions for different cases of building and catchment types. The work will provide information on the optimal retrofit types and design levels in the context of Australian construction costs and catchment behaviours.

\section{SUMMARY}

The economic losses due to floods have been increasing in recent decades due to vulnerable construction types and because of rapid urban development in floodplains. The increase in loss emphasises the need to improve flood risk management and to reduce future flood losses. These need to be built upon a sound analysis of flood hazard, typical floor types, potential losses and the effectiveness of different mitigation measures [29].

Flood risk management not only includes the measures taken by government but also includes mitigation measures adopted by private property owners to reduce the potential losses. These measures include elevating structures above the expected flood level, relocating the structure outside the floodplain, dry floodproofing to make the structure water tight, wet floodproofing by using water-resistant materials and installing storey barriers to keep water away from the building.

These efforts have a significant potential to reduce flood damage to buildings and contents particularly in low to moderate flood levels. Selection and implementation of any of these strategies would require comprehensive analyses of the characteristics of flood, local building standards and a cost benefit analysis to evaluate the optimum strategy.

This BNHCRC project aims to conduct a comprehensive analysis of mitigation options and evaluate each of them through cost benefit analysis for use in Australian conditions. The result would be a clear understanding of cost and benefits involved in implementing any of these mitigation measures. This evidence base will facilitate and encourage governments and property owners to make informed and optimal decisions to reduce flood risk.

\section{ACKNOWLEDGEMENTS}

The support of the Commonwealth of Australia through the Cooperative Research Centre program is acknowledged.

This paper is published with the permission of the CEO, Geoscience Australia.

\section{REFERENCES}

[1] Jonkman, S., Global perspectives of loss of human life caused by floods. Natural Hazards, 34, pp. 151-175, 2005.

http://dx.doi.org/10.1007/s11069-004-8891-3 
[2] HNFMSC, Reducing Vulnerability of Buildings to Flood Damage: Guidance on Building in Flood Prone Areas, Hawkesbury-Nepean Floodplain Management Steering Committee: Parramatta, 2006.

[3] Australian Building Code Board (ABCB), Construction of Buildings in Flood Hazard Areas, Standard Version 2012.2, Canberra, Australia, 2012.

[4] BNHCRC, Cost-effective mitigation strategy development for flood prone buildings, bushfire and natural hazards cooperative research centre, available at http://www. bnhcrc.com.au/research/resilient-people-infrastructure-and-institutions/243

[5] Maqsood, T., Wehner, M., Dale, K. \& Edwards, M., A schema to categorise residential building in Australian floodplains. Proceeding of the Floodplain Management Association National Conference, Brisbane, Australia, 2015.

[6] FEMA, Multi-hazard loss estimation methodology, flood model, HAZUS. Technical Manual. Federal Emergency Management Agency, Department of Homeland Security, Washington DC, USA, 2007.

[7] Schwarz, J. \& Maiwald, H., Damage and loss prediction model based on the vulnerability of building types. Proceeding of the 4th International Symposium on Flood Defence, Toronto: Canada, 2008.

[8] Pacheco, B., Hernandez, H., Castro, P., Tingatinga, E., Suiza, R., Tan, L., Lonalong, R., Vreon, M., Aquino, H., Macuha, R., Mata, W., Villalba, I., Pascua, M., Ignacio, U., Germar, F., Dino, J., Reyes, G., Tirao, J. \& Zarco, M., Development of Vulnerability Curves of Key Building Types in the Greater Metro Manila Area, Philippines, Institute of Civil Engineering, University of the Philippines Diliman, 2013.

[9] NIWA, Riskscape User Manual Version 0.2.30, available at https://riskscape.niwa. co.nz/

[10] Wehner, M., Maqsood, T., Corby, N., Edwards, M. \& Middelmann-Fernandes, M., Augmented vulnerability models for inundation, Technical report submitted to DCCEE, Geoscience Australia, Canberra, Australia, 2012.

[11] Maqsood, S., Wehner, M., Ryu, H., Edwards, M., Dale, K. \& Miller, V., GAR15 Vulnerability Functions: Reporting on the UNISDR/GA SE Asian Regional Workshop on Structural Vulnerability Models for the GAR Global Risk Assessment, 11-14 November, 2013, Geoscience Australia, Canberra, Australia, Record 2014/38. Geoscience Australia: Canberra, Australia, 2014. http://dx.doi.org/10.11636/Record.2014.038

[12] Bouwer, L., Poussin, J., Papyrakis, E., Daniel, V., Pfurtscheller, C., Thieken, A. \& Aerts, J., Methodology report on costs of mitigation. CONHAZ project report, Report number WP04_2, 2011.

[13] Kunreuther, H., Disaster mitigation and insurance: learning from Katrina. The Annals of the American Academy, 604, pp. 208-227, 2006.

http://dx.doi.org/10.1177/0002716205285685

[14] Crichton, D., Role of insurance in reducing flood risk. The Geneva Papers, 33, pp. 117-132, 2008.

http://dx.doi.org/10.1057/palgrave.gpp.2510151

[15] Burby, R., Deyle, R., Godschalk, D. \& Olshansky, R., Creating hazard resilient communities through land-use planning. Natural Hazards Review, 1, pp. 99-106, 2000. http://dx.doi.org/10.1061/(ASCE)1527-6988(2000)1:2(99)

[16] Poussin, J., Bubeck, P., Aerts, J. \& Ward, P., Potential of semi-structural and non-structural adaptation strategies to reduce future flood risk: case study for the Meuse. Natural Hazards and Earth Systems Science, 12, pp. 3455-3471, 2012.

http://dx.doi.org/10.5194/nhess-12-3455-2012 
[17] Brody, S., Kang, J. \& Bernhardt, S., Identifying factors influencing flood mitigation at the local level in Texas and Florida: the role of organizational capacity. Natural Hazards, 52, pp. 167-184, 2010. http://dx.doi.org/10.1007/s11069-009-9364-5

[18] Productivity Commission, Natural disaster funding arrangements. Productivity commission inquiry report no. 74, Canberra, Australia, ISBN 978-1-74037-524-5, 2014.

[19] FEMA, Engineering Principles and Practices for Retrofitting Flood-Prone Residential Structures, FEMA P-259, 3rd., Federal Emergency Management Agency, USA, 2012.

[20] USACE, Flood proofing; techniques, programs and references. National Flood Proofing Committee. US Army Corps of Engineers. Washington D.C., USA, 2000.

[21] USACE, Flood proofing; how to evaluate your options. National Flood Proofing Committee. US Army Corps of Engineers. Washington D.C., USA, 1993.

[22] Bartzis, N., Flood insurance pricing. Proc. of the Floodplain Management Association National Conference, Tweed Heads, Australia, 2013.

[23] FEMA, Natural hazards and sustainability for residential buildings. FEMA P-798. Federal Emergency Management Agency, USA, 2010.

[24] USACE, Raising and moving the slab-on-grade house with slab attached. National Flood Proofing Committee. US Army Corps of Engineers. Washington D.C., USA, 1990.

[25] FEMA, Selecting appropriate mitigation measures for floodprone structures. FEMA 551. Federal Emergency Management Agency, USA, 2007.

[26] Kreibich, H., Thieken, A., Petrow, T., Meuller, M. \& Merz, B. Flood loss reduction of private households due to building precautionary measures - lessons learned from the Elbe flood in August 2002. Natural Hazards and Earth Systems Science, 5, pp. 117-126, 2005. http://dx.doi.org/10.5194/nhess-5-117-2005

[27] FEMA, Floodproofing non-residential buildings. FEMA P-936. Federal Emergency Management Agency, USA, 2013.

[28] USACE, Flood proofing tests; tests of materials and systems for flood proofing structures. Floodplain Management Services Programs. National Flood Proofing Committee. US Army Corps of Engineers: Washington D.C., USA, 1988.

[29] Kreibich, H. \& Thieken, A., Assessment of damage caused by high groundwater inundation. Water Resources Research, 44, W09409. http://dx.doi.org/10.1029/2007WR006621

[30] FEMA, Flood damage-resistant materials requirements for buildings located in special flood hazard areas. NFIP Technical Bulletin 2. Federal Emergency Management Agency, USA, 2008.

[31] FEMA, Protecting Building Utilities From Flood Damage; Principles and Practices for the Design and Construction of Flood Resistant Building Utility Systems, FEMA P-348, 1st edn., Federal Emergency Management Agency, USA, 1999.

[32] Kreibich, H., Christenberger, S. \& Schwarze, R., Economic motivation of households to undertake private precautionary measures against floods, Natural Hazards and Earth Systems Science, 11, pp. 309-321, 2011. http://dx.doi.org/10.5194/nhess-11-309-2011

[33] Bluemont, Flood prevention, available at http://www.bluemont.com.au/flood-prevention 